\title{
Five-Year Analysis of Air Pollution in Istanbul Including Also the Impact of the COVID-19 Pandemic
}

\section{COVID-19 Pandemisinin Etkisiyle Birlikte İstanbul'da Son Beş Yılın Hava Kirliliği Değerlendirilmesi}

\author{
Nilüfer AYKAÇ®, Pınar BOSTAN $\odot$, Sabri Serhan OLCAY $\odot$, Berker ÖZTÜRK $\odot$
}

Cite as: Aykaç N, Bostan P, Olcay SS, Öztürk B. Five-year analysis of air pollution in Istanbul including also the impact of the COVID-19 pandemic. İzmir Göğüs Hastanesi Dergisi. 2021;35(3):113-24.

\begin{abstract}
Objective: Particulate matter, sulfur dioxide, ozone, and nitrogen oxide compounds are the main air pollutants. The purpose of this research is to analyze the five-year air quality of Istanbul and examine the effect of movement restrictions due to the COVID-19 pandemic on pollutants.

Method: The public data of the National Air Quality Observation Network has been utilized. The research has been conducted based on the five-year daily averages of $\mathrm{PM}_{1}, \mathrm{NO}_{2}$, and $\mathrm{NO}_{x}$ pollutants for Istanbul between 2016-2020. The data of stations which measured for $75 \%$ and more throughout the year has been used. The effect of lockdowns enforced due to COVID-19 was revealed by comparing data of pollutants from April and May of 2020 to the same period in 2019.

Results: There were 12 stations between 2016-2018, and 39 stations in 2019 and 2020 which measured particulate matter and nitrogen oxide compounds. Only 9 stations reached the standard of measuring pollution for $75 \%$ and more throughout the year. The $\mathrm{PM}_{10}, \mathrm{NO}_{2}$, and NOx levels measured by all the 9 stations between 2016-2020 are above the limit values set by the World Health Organization (WHO). The lockdowns in 2020 have not been helping improvements in air pollution issue. However, there have been regressions of $33.4 \%, 59.6 \%$, and $52.6 \%$ in the overall average particulate matter, nitrogen oxide, and nitrogen dioxide concentrations during the lockdowns between 23-26 of April, 1-3 of May, and 23-26 of May, respectively.

Conclusion: The air pollution issue in Istanbul has not improved in a meaningful and significant manner for the last five years. There is a significant deficiency in measuring traffic pollution. It has been found that two days long lockdowns and physical movement restrictions due to COVID-19 have significantly contributed to a significant regression in the overall concentration of air pollutants.
\end{abstract}

Keywords: Particulate matter, nitrogen compounds, COVID-19, lockdown

öz

Amaç: Partikül madde, kükürt dioksit, ozon ve nitrojen oksit bileșikleri temel hava kirleticileridir. Bu makalede İstanbul'un 5 ylllık hava kalitesi değerlendirmesi ve pandemi nedeniyle uygulanan fiziki hareket kısıtlamalarının kirleticiler üzerine olan etkisinin araştırılması amaçlanmıştıı.

Yöntem: Araştırmada Ulusal Hava Kalitesi İzleme Äğının kamuoyuna açık verileri kullanıldı. 2016-2020 yılları arasında İstanbul'da trafik yoğunluğunun neden olduğu temel kirleticiler olan partikül madde ve nitrojen bileşikleri analiz edildi. Bir yıl içinde ölçüm yapabildiği gün sayısı yüzdesi $\% 75$ ve üzeri değere ulaşan istasyonların verileri kullanıldı. Araştırmaya temel olan günlük $\mathrm{PM}_{10}, \mathrm{NO}_{2}$ ve $\mathrm{NO}_{\mathrm{x}}$ kirleticilerinin, 2016 yılından 2020 yılına dek 5 yıllık ölçüm verileri, İstanbul ili sınırları içerisinde ölçüm yapabilen tüm istasyonlarda 24 saatlik ortalamalar temel alınarak değerlendirildi. COVID-19 pandemisi nedeniyle 2020 yılı Nisan ve Mayıs aylarında gerçekleşen fiziki hareketliliği kısıtlama uygulamaları günlerindeki kirletici düzeyleri, her bir istasyon özelinde, 2019 ve 2020 yılları kıyaslanarak ayrıca değerlendirildi. Bulgular: 2016-2018 yılları arasında 12, 2019 ve 2020 yıllarında 39 adet istasyonda partikül madde ve nitrojen oksit bileșikleri ölçümü yapıldığı; bir yıl içinde ölcüm yapabildiği gün sayısı yüzdesi $\% 75$ ve üzeri değere ulaşan istasyon sayısının 9 adet olduğu tespit edildi. Son beş yıllık kirletici ölçümleri değerlendirildiğinde; araştırmaya dahil edilen 9 istasyonun tamamında, $\mathrm{PM}_{10}, \mathrm{NO}_{2}$ ve $\mathrm{NO}_{x}$ kirletici ölçümlerinin, Dünya Sağlık Örgütü'nün belirlediği sınır değerleri aștığı saptandı. COVID-19 kapsamında 2020 yılında uygulamaya konulan iki günlük fiziki hareket kısıtlamalarının kirleticiler üzerinde olumlu bir etkisi izlenmedi. Ancak 23-26 Nisan, 1-3 Mayıs ve 23-26 Mayıs tarihlerinde gerçekleştirilen kapanma dönemlerinde partikül madde, nitrojen oksit ve nitrojen dioksit konsantrasyonlarında sırasıyla ortalama $\% 33,4, \% 59,6$ ve $\% 52,6$ oranında düşüş saptandı.

Sonuc: İstanbul'daki hava kirliliği bes yıllık dönemde anlamlı ve belirgin bir azalma göstermemiștir. Son yıllarda özellikle trafik kirliliğini ölçmede yetersizlik mevcuttur. COVID-19 önlemleri çerçevesinde uygulamaya konulan iki günden uzun süreli ve etkili fiziki hareket kısıtlamaları hava kirleticilerinin konsantrasyonunda belirgin düşüşe yol açtığı tespit edilmiştir.

Anahtar kelimeler: Partikül madde, nitrojen bileşikleri, COVID-19, kapanma
Received/Geliş: 01.07.2021

Accepted/Kabul: 18.08.2021

First Published/Erken Çevrimiçi: 24.09.2021

Corresponding author/Sorumlu yazar:

N. Aykaç

ORCID: 0000-0003-1407-8258

Academic Hospital,

Göğüs Hastalıkları Kliniği,

İstanbul - Türkiye

niluferkongar@gmail.com

P. Bostan

ORCID: 0000-0001-5312-083X

Bilgi Üniversitesi, Sağlık Bilimleri Fakültesi,

İstanbul - Türkiye

S. S. Olcay

ORCID: 0000-0002-3737-5813

Muğla Sıtkı Koçman Üniversitesi,

Tıp Fakültesi, Göğüs Hastalıkları

Anabilim Dalı,

Muğla - Türkiye

B. Öztürk

ORCID: 0000-0002-8393-8111 Aksaray Eğitim ve Araştırma Hastanesi,

Göğüs Hastalıkları Kliniği, Aksaray - Türkiye

(c) Telif hakkı İzmir Göğüs Hastanesi'ne aittir. Logos Tıp Yayınclık tarafından yayınlanmaktadır.

Bu dergide yayınlanan bütün makaleler Creative Commons 4.0 Uluslararası Lisansı (CC BY) ile lisanslanmıștır. 


\section{INTRODUCTION}

Air pollution is a significant public health problem causing deaths and diseases at a global level. While it predominantly causes health problems on the respiratory, cardiovascular, and cerebrovascular systems, in 2013, the International Agency for Research on Cancer (IARC) has also classified it as a Group 1 carcinogenic, stated that there was enough evidence to connect it with lung cancer and that it increases the risk of bladder cancer ${ }^{(1,2)}$. Recent research on the topic has found that vulnerable populations such as the children, elderly, pregnant women, and people from lower socio-economic backgrounds are more open to the effects of air pollution, and a 10 $\mu \mathrm{g} / \mathrm{m}^{3}$ increase of $\mathrm{PM}_{10}$ is found to increase the mortality by $0.4-0.8 \%$ in short-term exposures ${ }^{(3)}$. Furthermore, outdoor air pollution caused by irregular urbanization and industrialization leads to the death of 3,2 million people every year globally ${ }^{(4)}$.

Sulfur dioxide $\left(\mathrm{SO}_{2}\right)$, nitrogen oxides $\left(\mathrm{NO}_{2}\right.$, $\left.\mathrm{NO}_{\mathrm{x}}\right)$, ozone $\left(\mathrm{O}_{3}\right)$, carbon monoxide $(\mathrm{CO})$, volatile organic compounds (VOCs), and particulate matter $\left(\mathrm{PM}_{10}\right.$ and $\left.\mathrm{PM}_{2.5}\right)$ are the main pollutants of air. Particulate matter, which is one of the main air pollutants in Turkey, consists of carbon, heavy metals, inorganic ions, and polycyclic aromatic hydrocarbons. PM with a diameter of between 2.5-10 $\mu \mathrm{m}$ is identified as coarse, while PM with a diameter of $2.5 \mu \mathrm{m}$ and less is identified as fine ${ }^{(5)}$. It has been proved that the pathogenic effect of the PM with less diameter is more on a variety of bodily systems via systemic circulation ${ }^{(6,7)}$. There is strong evidence on the effects of short-term exposure to $\mathrm{PM}_{10}$ on respiratory health, but $\mathrm{PM}_{2.5}$ is known to be a stronger risk factor for mortality and especially for long-term exposure compared to $P M_{10}{ }^{(8)}$. Every $\mu \mathrm{g} / \mathrm{m}^{3}$ increase in $P M_{10}$ increases the daily mortality rates by $0.2-0.6 \%{ }^{(9)}$.

A high concentration of nitrogen oxide compounds causes irritation in airways and the development of asthma, as well as increasing the susceptibility to respiratory tract infections. PM and nitrogen oxide compounds emerge predominantly out of the use of fossil fuels in industry, transport, and heating. The nitrogen dioxide emissions emanate as a result of reaction with sunlight which makes $\mathrm{NO}_{x}$ an important air pollutant for countries receiving a lot of sun, such as Turkey. Nitrogen compounds occur in combustion processes, which are the main sources of anthropogenic emissions such as road and other transportation processes, energy generationdistribution, industrial processes ${ }^{(10)}$.

The aim of this research is to examine the change of air quality in Istanbul based on the changes in the concentration of $\mathrm{PM}_{10}$ and nitrogen compounds by using the public data collected between the years 2016-2020 by the air quality stations which are part of the National Air Quality Observation Network. The effects of the COVID19 pandemic and the physical movement restrictions as part of the response to it since the first case was spotted in Turkey on March 11, 2020 , on the air quality of Istanbul have been specifically analyzed as part of this research.

\section{MATERIAL and METHODS}

The measurements of the air pollutants examined in the research were retrieved from the databank for Istanbul which is situated on the website of the National Air Quality Observation Network operating under the Ministry of Environment and Urbanization. The main pollutants of PM and nitrogen compounds produced by heavy traffic were chosen among other pollutants available in the databank. $\mathrm{PM}_{10}$ measurements were analyzed instead of $\mathrm{PM}_{2.5}$ because its measurements were not sufficient for analysis. $\mathrm{SO}_{2}$ measurements were left out of the research. The analysis was conducted by making use of 24-hour average values calculated based on the five-year measurements of the main pollutants chosen for the research, which are $\mathrm{PM}_{10}, \mathrm{NO}_{2}$, and $\mathrm{NO}_{x}$, within the borders of Istanbul between 2016-2020.

As stated in the Air Quality Assessment and Management Regulation, the minimum data 
acquisition required of the stations which conduct constant measurement was accepted as $90 \%$, and stations with this measurement quality were determined ${ }^{(11)}$. However, in accordance with the qualification definition set by the European Environment Agency (EEA) for the comparison of five-year data of $\mathrm{PM}_{10}$ and nitrogen compounds, the data of the stations which measured $75 \%$ and more of the year were used (12). The annual average values of 5 consecutive years between 2016 and 2020 were compared based on the data retrieved from the stations included in the study. And the analysis was predicated on the limit values set by the WHO ${ }^{(13)}$.

Pollutant levels during the lockdowns lasting two days, which occurred in April and May 2020 due to the COVID-19 pandemic, were separately evaluated for each station by comparing the years 2019 and 2020. The restrictions enforced by the public authorities in 11-12,18-19, and 23-26 of April, and 1-3, and 23-26 of May in 2020 to limit physical movement have been identified as lockdown for our research. The measurements made on these days were compared with the same dates of the previous year to investigate the effect of these lockdowns on air pollution.

This research did not receive ethical approval because the validated public data of the National Air Quality Observation Network under the Ministry of Environment and Urbanization was utilized without any attempt to include data from human participants, especially the vulnerable groups.

\section{RESULTS}

Istanbul is the most crowded city in Turkey with a population of over 15 million on a 5342 $\mathrm{km} 2$ area ${ }^{(14)}$. There were 12 stations between the years 2016-2018, and 39 stations in 2019 and 2020 in Istanbul that measured particulate matter and nitrogen oxide compounds according to the public data of the National Air Quality Observation Network. PM 10 measurements in Istanbul reached $75 \%$ of the year between $2016-2018$, and $84 \%$ of the year between 2019-2020. $\mathrm{NO}_{2}$ measurements were made over $90 \%$ of the year between 2016 2017, however, this performance was not kept up and only $33 \%$ of the stations that reached the standard measured $\mathrm{NO}_{2}$. For $\mathrm{NOx}, 23 \%$ of the stations that reached standard measured $\mathrm{NO}_{\mathrm{x}}$, meaning that only 9 out of 39 stations in Istanbul measured NOx for $90 \%$ and more of the year (Table 1).

Between 2016-2020, there were 7 stations in Istanbul that measured $\mathrm{PM}_{10}, \mathrm{NO}_{2}$, and $\mathrm{NOx}$ constantly, and the measurements of which reached $90 \%$ and more of the year; and there were 9 stations that measured $75 \%$ and more of the year. The data on pollutants according to years which was provided by the 9 stations included in the research can be seen in Table 2 .

The WHO's limit value for $\mathrm{PM}_{10}$ pollutant (20 $\mu \mathrm{g} / \mathrm{m}^{3}$ ) has been recorded to exceed in all the 9 stations included in the research in the last five years. The stations in Esenyurt and Mecidiyeköy districts measure the highest $\mathrm{PM}_{10}$ values (Figure 1).

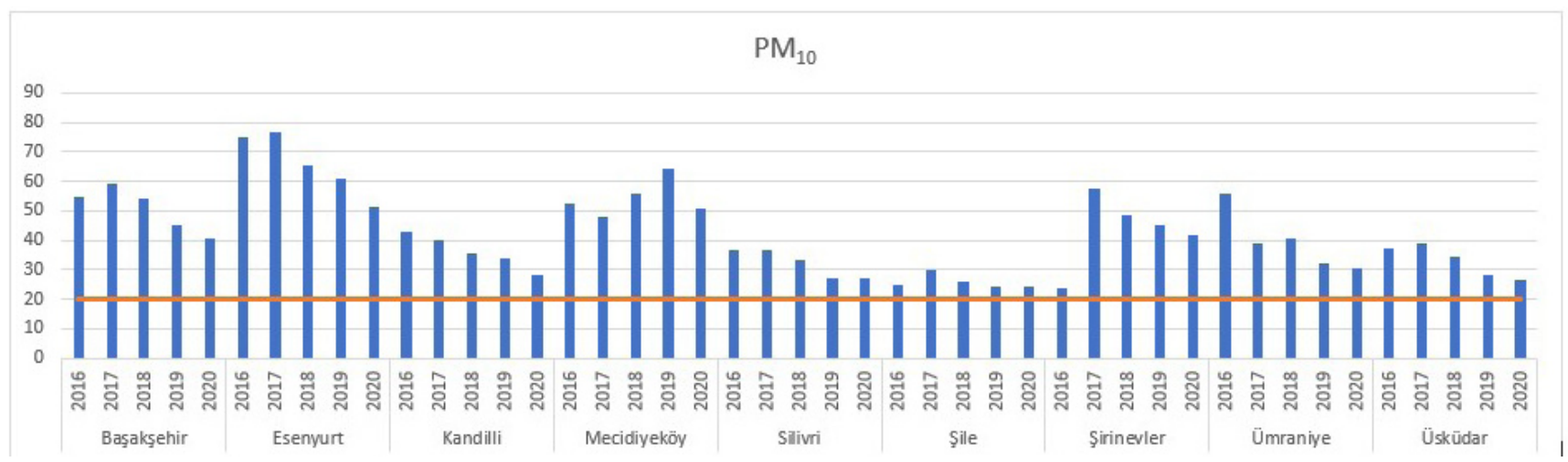

Figure 1. Annual averages of $\mathbf{P M}_{10}$ recorded for 5 consecutive years between 2016-2020. 


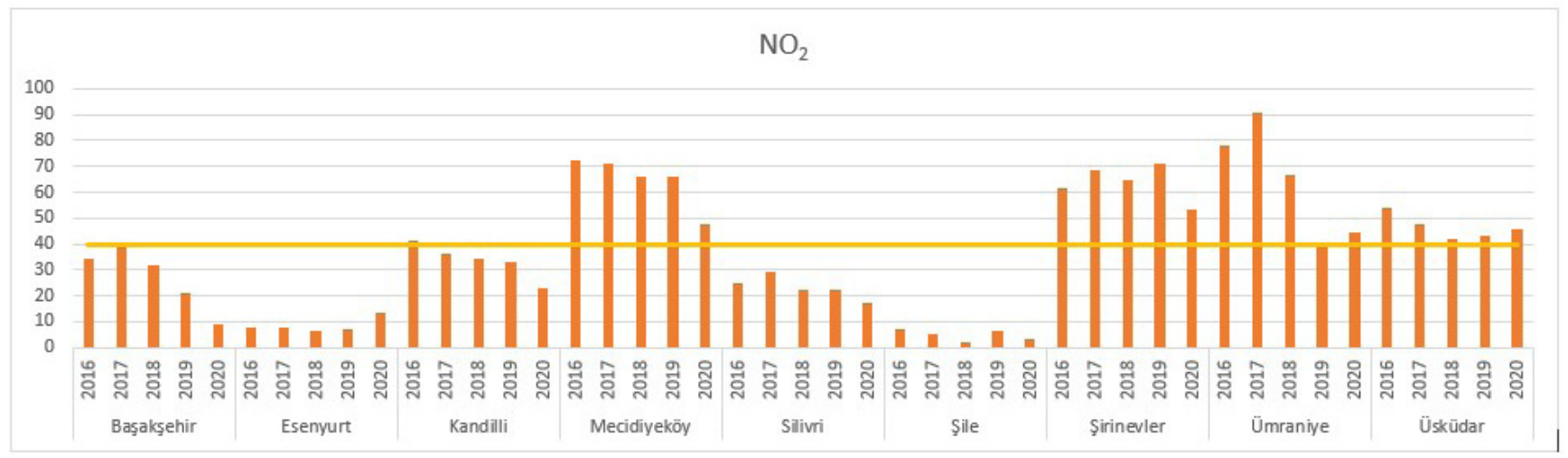

Figure 2. Annual averages of $\mathrm{NO}_{2}$ recorded for 5 consecutive years between 2016-2020.

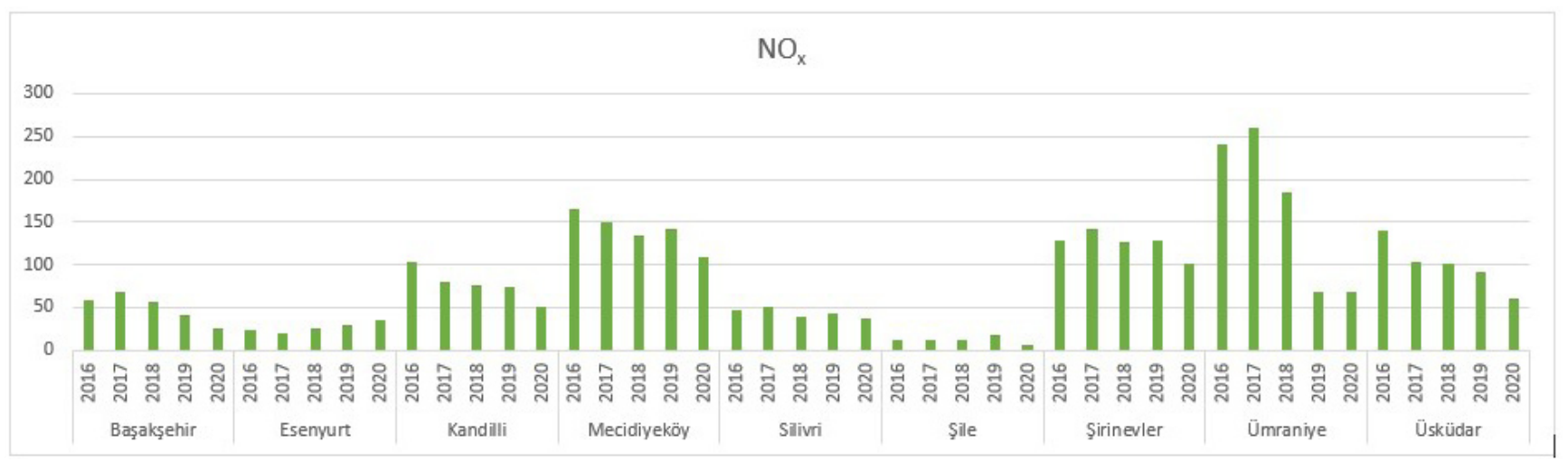

Figure 3. Annual averages of $\mathrm{NO}_{\mathrm{x}}$ recorded for 5 consecutive years between 2016-2020.

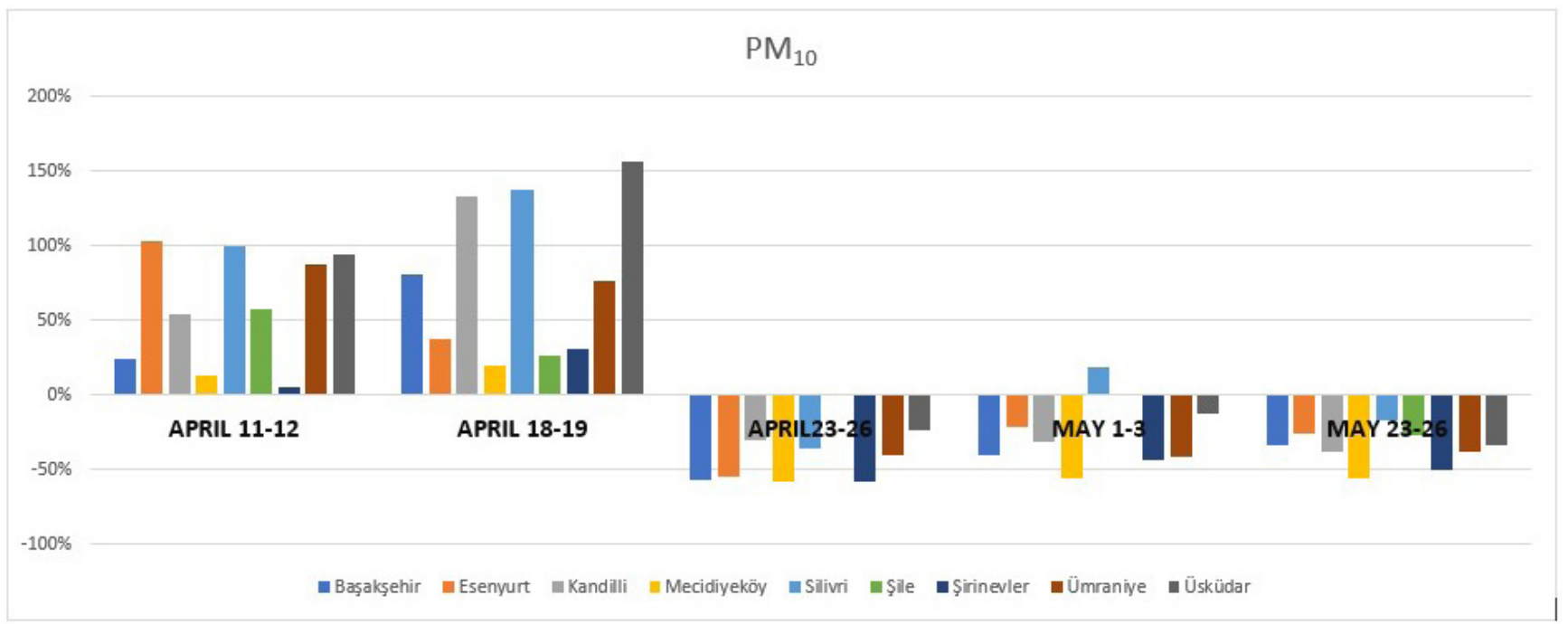

Figure 4. Change of $\mathbf{P M}_{10}$ levels in Istanbul during lockdowns in 2020 compared to the same dates in 2019.

The WHO's annual limit value of $40 \mu \mathrm{g} / \mathrm{m}^{3}$ for $\mathrm{NO}_{2}$ has been recorded to exceed in Mecidiyeköy, Ümraniye, Şirinevler, Üsküdar districts (Figure 2). As for $\mathrm{NO}_{x}$, the WHO's annual limit value of 30 $\mu \mathrm{g} / \mathrm{m}^{3}$ has been recorded to exceed in all 9 of the stations included in the research. Among all the stations, the station in Ümraniye recorded the highest pollution in terms of $\mathrm{NO}_{\mathrm{x}}$ (Figure 3 ).

The comparison of pollution data in the dates in 2020 in which lockdowns were enforced with 


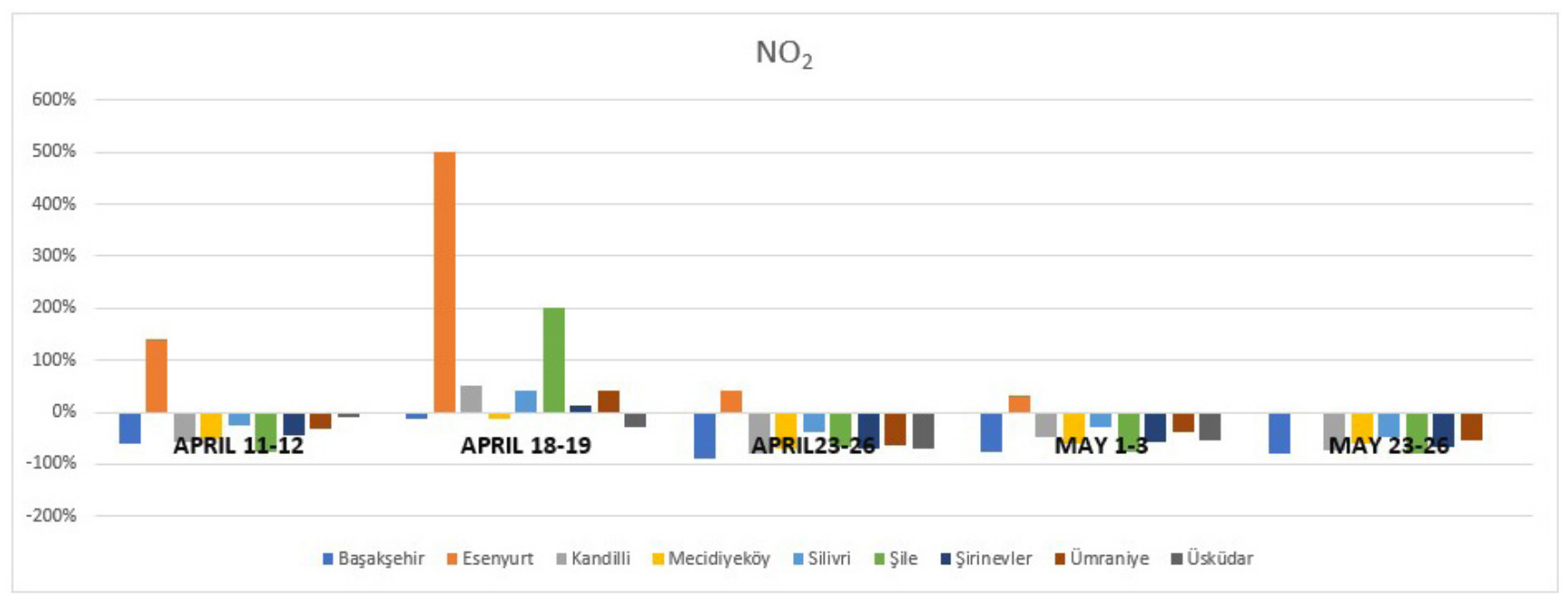

Figure 5. Change of $\mathrm{NO}_{2}$ levels in Istanbul during lockdowns in 2020 compared to the same dates in 2019.

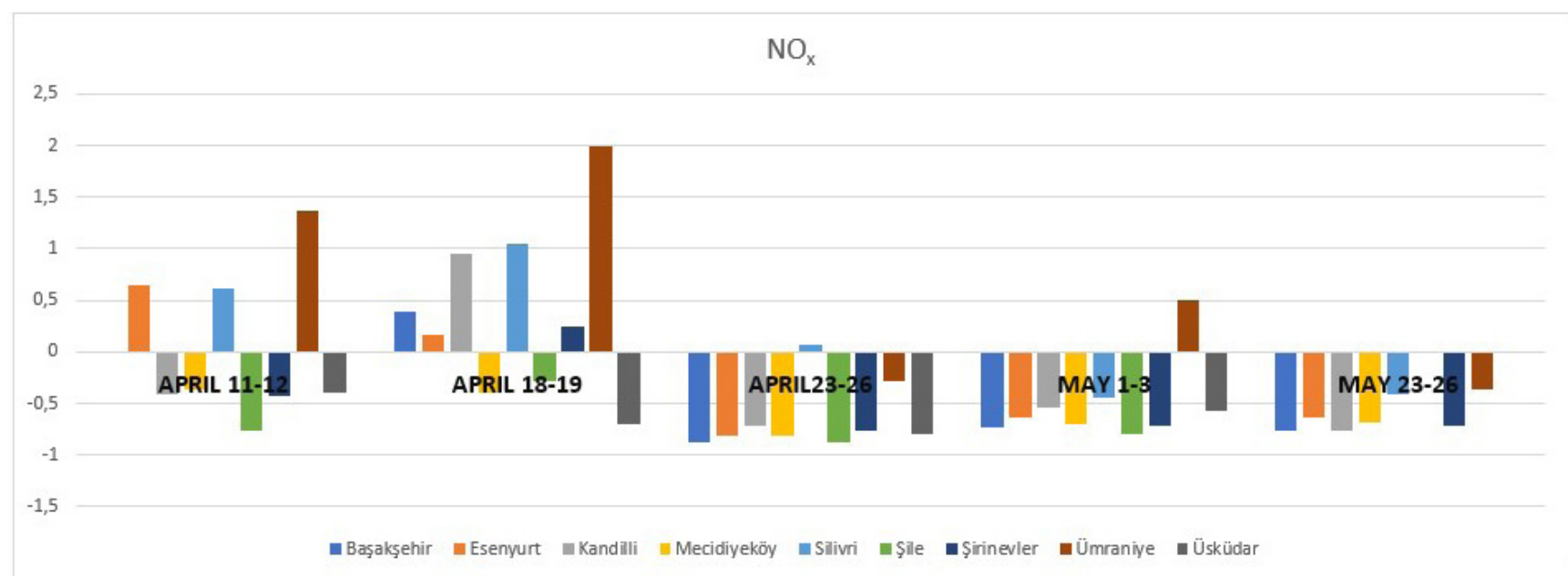

Figure 6. Change of $\mathrm{NO}_{x}$ levels in Istanbul during lockdowns in 2020 compared to the same dates in 2019.

the same dates in 2019 revealed that the lockdowns on 11-12 of April and 18-19 of April in 2020 did not lead to a regression in the amount of particulate matter pollution (Figure 4 ). On the other hand, lockdowns in 23-26 of April, 1-3 of May, and 23-26 of May 2020 which lasted three or four days led to a regression in both the particulate matter and the nitrogen compounds pollution (Figure 4, 5, 6). There were regressions in the concentrations of nitrogen compounds measured in the stations of Mecidiyeköy and Üsküdar, where the pollution levels are normally high due to heavy traffic, during the lockdowns in 11-12 of April and 18-19 of April in 2020 (Figure $5,6)$. According to the traffic data on April and
May 2020, the hourly traffic was observed to be less busy on the days of lockdown (Figure 7, 8) (15).

During the lockdowns on 23-26 of April, 1-3 of May, and 23-26 of May which lasted three or four days, all the stations observed an average regression of $33.4 \%, 59.6 \%$, and $52.6 \%$ in particulate matter, nitrogen oxide and dioxide concentrations, respectively. While it was observed that there was an average of $25.1 \%$, $51.5 \%$, and $44.4 \%$ regression in particulate matter, nitrogen oxide and dioxide concentrations, respectively, during the lockdown lasting three days on 1-3 of May; the average regression in the concentrations of the pollutants were recorded as 


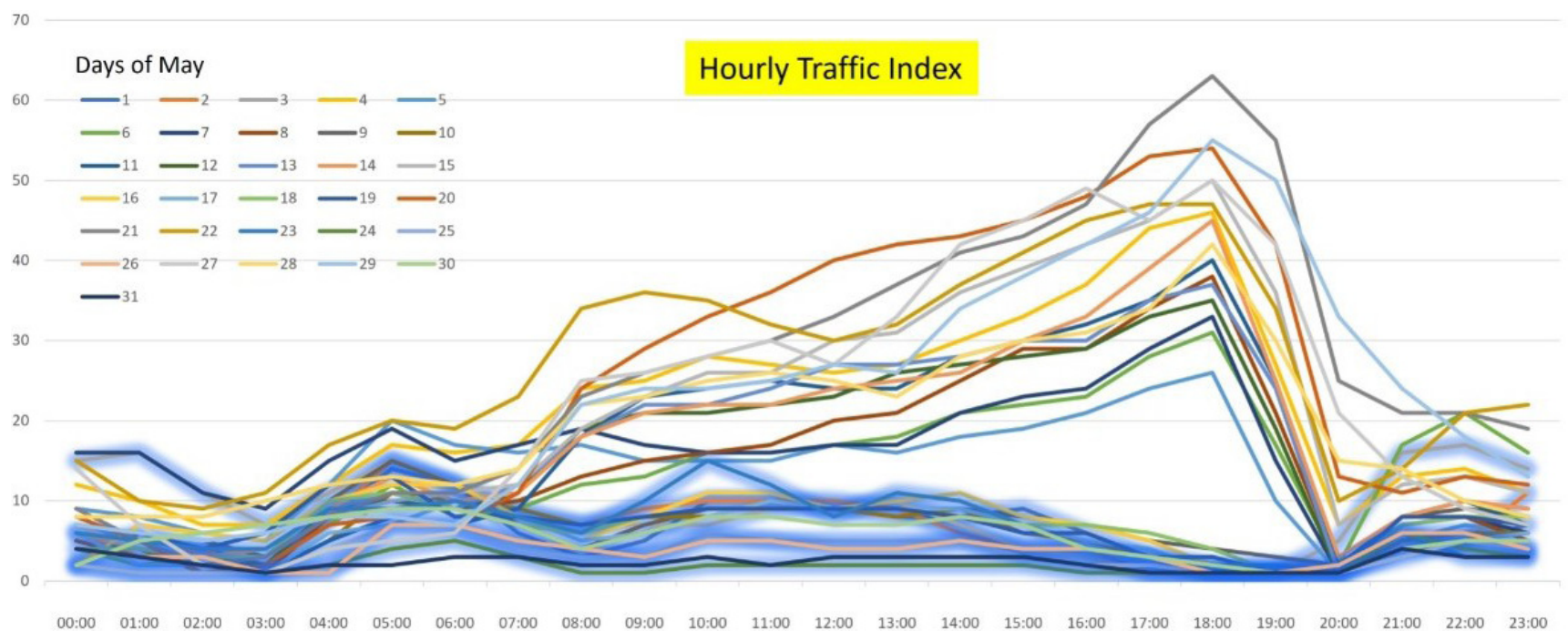

Figure 7. Hourly Traffic Index according to the Istanbul Metropolitan Municipality data during the April 2020 Lockdowns (lockdown days are shaded blue).

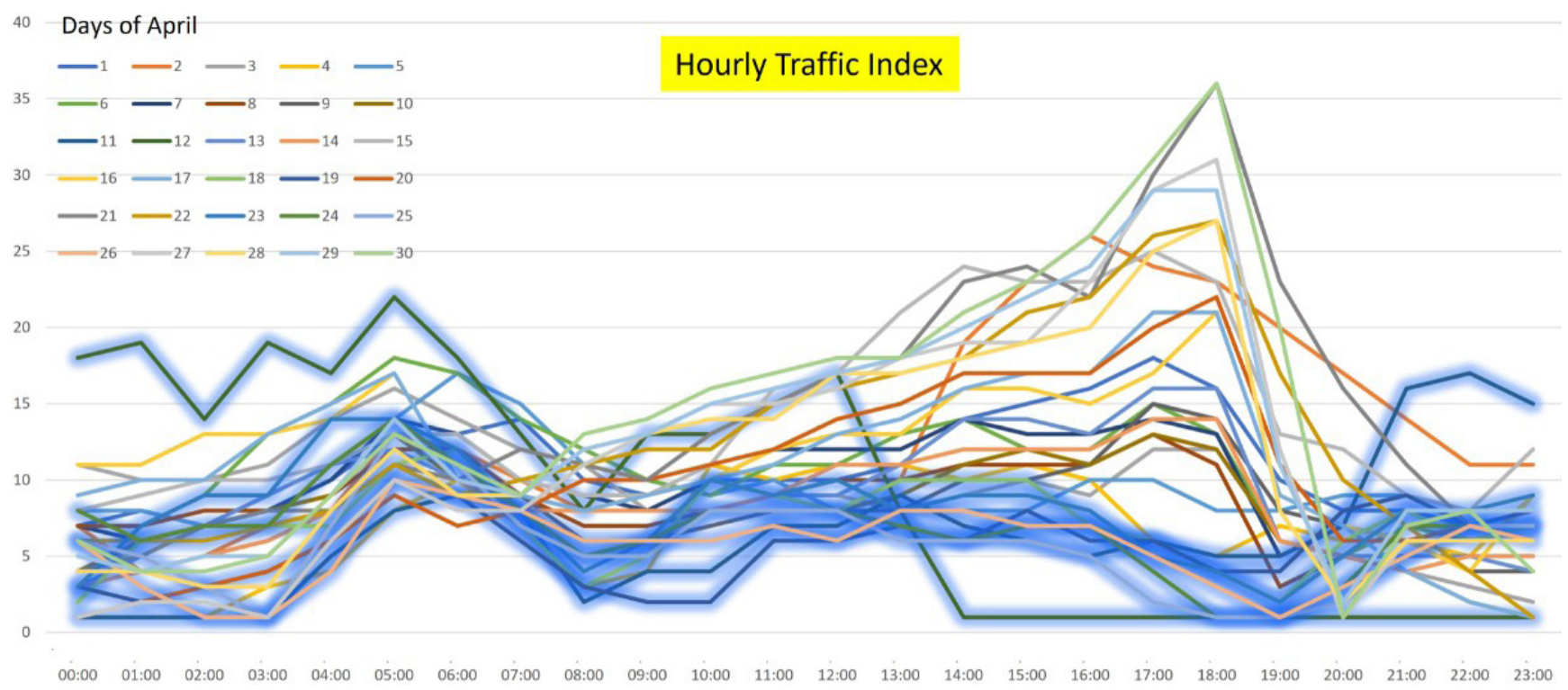

Figure 8. Hourly Traffic Index according to the Istanbul Metropolitan Municipality data during the May 2020 Lockdowns (lockdown days are shaded blue).

$37.5 \%, 63.6 \%$, and $56.6 \%$ during the two lockdowns lasting four days (Figure 4, 5, 6).

\section{DISCUSSION}

This research revealed that the air pollution problem of Istanbul has not improved significantly between the years 2016-2020, that, on the contrary, it became a permanent problem in certain districts, and that air quality monitoring is not adequate due to the inability of stations to measure the pollution created by heavy traffic in Istanbul. Furthermore, it has been revealed that lockdowns longer than two days enforced due to COVID-19 have been influential on the regression of air pollution levels recorded in Istanbul in 2020.

The first step to improve the air quality is to constantly monitor the air pollutants. The condition underlying this is the establishment of a sufficient 
Table 1. The number of stations that can reach the measurement quality criteria of the Air Quality Assessment and Management Regulation and the European Environment Agency by years.

\begin{tabular}{|c|c|c|c|c|c|c|c|}
\hline \multicolumn{2}{|c|}{} & \multicolumn{2}{|c|}{$\mathrm{PM}_{10}$} & \multicolumn{2}{c|}{ NO $_{2}$} & \multicolumn{2}{c|}{ NO $_{\mathbf{x}}$} \\
\hline Year & Number of stations & $\geq \% \mathbf{9 0}$ & $\geq \% \mathbf{7 5}$ & $\geq \% \mathbf{9 0}$ & $\geq \% \mathbf{7 5}$ & $\geq \% \mathbf{9 0}$ & $\geq \% \mathbf{7 5}$ \\
\hline 2016 & 12 & 9 & 9 & 12 & 12 & 12 & 12 \\
\hline 2017 & 12 & 9 & 9 & 12 & 12 & 12 & 12 \\
\hline 2018 & 12 & 8 & 9 & 10 & 12 & 9 & 12 \\
\hline 2019 & 39 & 33 & 35 & 30 & 31 & 28 & 31 \\
\hline 2020 & 39 & 22 & 33 & 13 & 26 & 9 & 12 \\
\hline
\end{tabular}

Table 2. Annual measurement percentages of the stations by years and pollutants (measurement days / 365 days).

\begin{tabular}{|c|c|c|c|c|c|c|c|c|c|c|c|c|c|c|c|}
\hline & \multicolumn{5}{|c|}{$\mathrm{PM}_{10}$} & \multicolumn{5}{|c|}{$\mathrm{NO}_{2}$} & \multicolumn{5}{|c|}{$\mathrm{NO}_{\mathrm{x}}$} \\
\hline & 2016 & 2017 & 2018 & 2019 & 2020 & 2016 & 2017 & 2018 & 2019 & 2020 & 2016 & 2017 & 2018 & 2019 & 2020 \\
\hline $\begin{array}{c}\text { Başakşehir } \\
\text { MTHM }\end{array}$ & 95 & 94 & 98 & 95 & 94 & 96 & 94 & 97 & 96 & 92 & 96 & 94 & 97 & 96 & 89 \\
\hline $\begin{array}{c}\text { Esenyurt } \\
\text { MTHM }\end{array}$ & 99 & 95 & 86 & 91 & 95 & 98 & 97 & 89 & 92 & 94 & 98 & 96 & 88 & 92 & 93 \\
\hline $\begin{array}{c}\text { Kandilli } \\
\text { MTHM }\end{array}$ & 97 & 95 & 95 & 93 & 95 & 95 & 99 & 98 & 95 & 97 & 96 & 99 & 97 & 95 & 95 \\
\hline $\begin{array}{c}\text { Mecidiyeköy } \\
\text { MTHM }\end{array}$ & 96 & 97 & 92 & 95 & 90 & 98 & 98 & 95 & 95 & 94 & 98 & 98 & 94 & 95 & 94 \\
\hline $\begin{array}{c}\text { Silivri } \\
\text { MTHM }\end{array}$ & 93 & 96 & 97 & 98 & 98 & 96 & 98 & 99 & 98 & 98 & 96 & 98 & 97 & 97 & 97 \\
\hline $\begin{array}{c}\text { Şile } \\
\text { MTHM }\end{array}$ & 99 & 99 & 97 & 99 & 97 & 99 & 98 & 97 & 98 & 96 & 99 & 99 & 89 & 97 & 85 \\
\hline $\begin{array}{c}\text { Şirinevler } \\
\text { MTHM }\end{array}$ & 99 & 97 & 99 & 95 & 97 & 99 & 100 & 97 & 97 & 97 & 99 & 100 & 97 & 97 & 97 \\
\hline $\begin{array}{c}\text { Ümraniye } \\
\text { MTHM }\end{array}$ & 96 & 92 & 92 & 97 & 97 & 98 & 96 & 75 & 99 & 96 & 96 & 96 & 75 & 99 & 96 \\
\hline $\begin{array}{l}\text { Üsküdar } \\
\text { MTHM }\end{array}$ & 94 & 95 & 94 & 98 & 95 & 97 & 96 & 98 & 96 & 97 & 97 & 96 & 98 & 88 & 90 \\
\hline
\end{tabular}

MTHM: Marmara Clean Air Center

amount of stations that conduct adequate and accurate measurements. The number of air quality observation stations in Istanbul, although increasing in number recently, is insufficient compared to stations situated around the world. While, London with 9 million population over a $1.572 \mathrm{~km}^{2}$ area has 120 stations; Tokyo with 9 million population over a $2.194 \mathrm{~km}^{2}$ area has 82 stations; New York with 8 million population over a $784 \mathrm{~km}^{2}$ area has 50 stations that monitor air quality; Istanbul, which is the most crowded city of Turkey has only 39 permanent stations ${ }^{(14,16,}$ ${ }^{17,18)}$. As we have revealed in our study, beyond the numerical insufficiency of stations, the number of stations that sufficiently measure nitrogen compounds throughout the whole year between 2016-2020 has been decreasing instead of increasing. Indeed, these quantitative and qualitative insufficiencies hinder the monitoring of air quality in a nuanced manner.

Research data reveals that the proportional increase of particulate matter pollution in Turkey 
over the years, in comparison to European countries, has been against improvements in Turkey's air pollution problem. Even when only $\mathrm{PM}_{10}$ is considered, particulate matter pollution in Turkey in 2003 was $5.6 \%$ more compared to Europe, and this rate has reached 31\% in 2019 because the particulate matter pollution in European countries has regressed by $14.2 \%$, while there has been an increase by $8.4 \%$ in Turkey during the same period ${ }^{(12,19)}$.

Several research and reports point out particulate matter pollution in Turkey as an important public health problem ${ }^{(20)}$. Pala et al. ${ }^{(21)}$ found in their study that the measurements were not adequately conducted by air quality stations throughout the year $(47.6 \%)$, that $\mathrm{PM}_{2.5}$ was measured by only $18.6 \%$ of the stations which collected sufficient data, and that, in 2018, longterm exposure to $\mathrm{PM}_{2.5}$ in lead to the premature death of 44,617 people. Çapraz et al. ${ }^{(22)}$ revealed in their Istanbul-based study conducted between 2013-2015 that an increasing number of hospital visits due to respiratory problems have been connected to short-term exposure to $\mathrm{PM}_{10}, \mathrm{PM}_{2.5}$, and $\mathrm{NO}_{2}$. The results were most strongly related to $\mathrm{PM}_{2.5}$ pollutant, and women and the elderly were found to be more susceptible to the risk of breathing polluted air ${ }^{(22)}$.

The number of studies about pollution by nitrogen compounds in Turkey is very limited. In a study conducted in Çanakkale, which evaluated $\mathrm{NO}_{2}$ along with industrial pollutants, the data collection area was divided into 3 regions, and data on $\mathrm{PM}, \mathrm{SO}_{2}, \mathrm{NO}_{2}$, and ozone pollutants and Pulmonary Function Test (PFT) scores were analyzed; and the PFT values were found to be worse in industrialized areas with more pollution ${ }^{(23)}$.

Our research is the first to evaluate both $\mathrm{NO}_{2}$ and $\mathrm{NO}_{x}$ pollutants together in the city of Istanbul and to reveal the limit value excesses measured by the stations included in the research. Nitrogen oxide and nitrogen dioxide pollution have been found to reach very high levels in certain districts of the city with heavy traffic and dense population. One of the results of our study is especially important: the positive influence of lockdowns lasting longer than two days (23-26 of April, 1-3 of May, and 23-26 of May) on nitrogen compounds pollution has been significant and consistently observed in all the stations included in the research. Since nitrogen compounds pollution is predominantly traffic-related, it is necessary to expand public transportation and to promote renewable energy use in private vehicles for the health of people living in Istanbul.

The first confirmed case of COVID-19 in Turkey was announced by the Ministry of Health on the 11 th of March, 2020, on the same day as the WHO's declaration of the pandemic. The countries around the world worked to limit the spread of the disease without a clear and effective treatment by restricting physical movement on a large scale through "lockdowns", limiting the contact between people, and by vaccination developed recently ${ }^{(24-27)}$. In this context, global and local travels were canceled all over the world, education was suspended in many countries, businesses and industrial activities were suspended, albeit temporarily. The suspension of industrial activities, on the other hand, led to a decrease in air pollutant emissions alongside reducing the speed of the epidemic. Air quality data retrieved from satellite and ground air quality stations showed significant reductions in the concentrations of air pollutants, particularly nitrogen compounds (28-30). In addition to nitrogen compounds, regressions in the particulate matter were also observed during the lockdown periods ${ }^{(31,32)}$. The Air Quality 2020 Report published by the European Union has shown that there is a regression in $\mathrm{PM}_{10}$ concentrations due to movement restrictions, although it is not as obvious as nitrogen dioxide pollutant ${ }^{(19)}$. In our research, a regression was observed for all pollutants within the scope of the research during the suspension of almost all the industrial activities, the reduction of traffic mobility, and the restriction of physical mobility for more than two days.

Restriction of physical mobility is the most important non-pharmacological approach to 
control the COVID-19 pandemic where a vaccine and a reliable medical treatment do not exist ${ }^{(33)}$. Our research shows that restrictions on physical mobility, named "lockdown" in our research, also have a positive effect on air pollutants. Similarly, studies revealed that restrictions of movement in the United States, China, France, Spain, and Italy have resulted in regressions of up to $60 \%$ in nitrogen dioxide concentration ${ }^{(34-39)}$. In fact, after a partial lockdown, a $77.3 \%$ regression in nitrogen oxide and $54.3 \%$ regression in nitrogen dioxide concentrations were observed in Brazil when compared to the five-year average values ${ }^{(40)}$. A study that included 44 cities in China found that, after travel restrictions and reduced social mobility, there was a regression of $6.76 \%$, $5.93 \%, 13.66 \%, 24.67 \%$, and $4.58 \%$ in $\mathrm{SO}_{2}$, $\mathrm{PM}_{2.5}, \mathrm{PM}_{10}, \mathrm{NO}_{2}$, and $\mathrm{CO}$ concentrations, respectively (41). Similarly, another study conducted in China revealed that the air quality index (AQI) has been better by $12.2 \%$ in cities where "lockdown" provisions were enforced ${ }^{(42)}$. A study that included 6 cities of India where physical movement restrictions were enforced showed a regression trend in tropospheric $\mathrm{NO}_{2}$ concentrations ${ }^{(43)}$. Furthermore, it is striking that regressions in nitrogen oxide concentrations in relation to restrictions on physical movement were observed in regions with heavy traffic ${ }^{(44)}$. In addition, a study conducted in the USA showed that there was an increase in $\mathrm{PM}_{2.5}$ concentration due to the increased use of biomass during the "lockdown" periods ${ }^{(45)}$. A study investigating the effects of physical movement restrictions put into practice due to COVID-19 on air quality in Turkey found that $\mathrm{PM}_{10}$ and $\mathrm{SO}_{2}$ were lower compared to previous five-year measurements ${ }^{(46)}$. A recent study on the same topic conducted in Istanbul revealed that significant regressions in $\mathrm{PM}_{10}, \mathrm{SO}_{2}, \mathrm{CO}$, $\mathrm{NO}_{2}, \mathrm{NO}, \mathrm{NO}_{x}$, and $\mathrm{O}_{3}$ concentrations were observed during the partial lockdowns ${ }^{(47)}$. By concentrating on particulate matter and nitrogen compounds, our study has reached the important conclusion that lockdowns longer than two days have a stronger positive influence on the improvement of air pollution in Istanbul.

In our study, the $P M_{10}$ concentration increased in all stations during the lockdowns on 11-12 of April and 18-19 of April 2020, compared to the same days of the previous year. In our opinion, this unexpected discordance may be secondary to the increased use of fossil fuels in households due to lockdowns, as Mendez-Espinosa et al. ${ }^{(45)}$ have also identified. As a matter of fact, the same increase is not observed by the stations outside the district of Silivri during lockdowns in May 2020, when we expect the use of fossil fuels to decrease due to seasonal effects.

The most important limitation of our research is the insufficient number of stations that conduct adequate and consistent measurements throughout the five-year study period. This limitation, which is independent of the structural design of our research, hinders the detailed monitoring of air quality over the years for Istanbul in general. Nevertheless, our research, which was carried out with available data, is important in terms of showing the recent situation of air pollutants, the process of development over the years, and the effect of the lockdowns enforced due to the COVID-19 pandemic in a very crowded metropolis like Istanbul.

\section{Main Points}

- There are insufficiencies in qualitative and quantitative monitoring of air pollution in Istanbul.

- Air pollution problem of Istanbul has not improved in a significant manner in the last five years.

- It has been found that lockdowns longer than two days enforced due to the COVID-19 pandemic have led to average regressions of $33,4 \%, 59,6 \%$, and $52,6 \%$ in particulate matter, nitrogen oxide, and nitrogen dioxide concentrations, respectively. 
Ethics Committee Approval: This research did not receive ethical approval because the validated public data of the National Air Quality Observation Network under the Ministry of Environment and Urbanization was utilized without any attempt to include data from human participants, especially the vulnerable.

\section{Conflict of Interest: There is no conlict interest.}

Funding: No financial support was received for the study.

\section{REFERENCES}

1. Thurston GD, Kipen H, Annesi-Maesano I, Balmes J, Brook RD, Cromar K, et al, Brunekreef B. A joint ERS/ATS policy statement: what constitutes an adverse health effect of air pollution? An analytical framework. Eur Respir J. 2017 Jan 11;49(1):1600419 https://doi.org/10.1183/13993003.00419-2016

2. International Agency for Research on Cancer, 'Outdoor air pollution a leading environmental cause of cancer deaths', Press release No 221, 2013. https://www.iarc. $\mathrm{fr} /$ news-events/iarc-outdoorair-pollution-a-leadingenvironmental-cause-of-cancerdeaths/

3. Katsouyanni K, Touloumi G, Samoli E, Gryparis A, Le Tertre A, Monopolis Y, et al. Confounding and effect modification in the short-term effects of ambient particles on total mortality: results from 29 European cities within the APHEA2 project. Epidemiology. 2001 Sep;12(5):521-31. https://doi.org/10.1097/00001648-200109000-00011

4. Lim SS, Vos T, Flaxman AD, Danaei G, Shibuya K, AdairRohani $\mathrm{H}$, et. al. A comparative risk assessment of burden of disease and injury attributable to 67 risk factors and risk factor clusters in 21 regions, 1990-2010: a systematic analysis for the Global Burden of Disease Study 2010. Lancet. 2012 Dec 15;380(9859):2224-60.

5. Yu JZ, Huang XH, Ho SS, Bian Q. Nonpolar organic compounds in fine particles: Quantification by thermal desorption-GC/MS and evidence for their significant oxidation in ambient aerosols in Hong Kong. Anal Bioanal Chem 2011;401(10):3125-39. https://doi.org/10.1007/s00216-011-5458-5

6. Dockery DW, Stone PH. Cardiovascular risks from fine particulate air pollution. N Engl J Med. 2007;356:511-3. https://doi.org/10.1056/NEJMe068274

7. Brook RD, Rajagopalan S, Pope CA, Brook JR, Bhatnagar A, Diez-Roux AV, et al; American Heart Association Council on Epidemiology and Prevention, Council on the Kidney in Cardiovascular Disease, and Council on Nutrition, Physical Activity and Metabolism. Particulate matter air pollution and cardiovascular disease: An update to the scientific statement from the American Heart Association. Circulation. 2010 Jun 1;121(21):233178. https://doi.org/10.1161/CIR.Ob013e3181dbece1

8. Nazarenko Y, Pal D, Ariya PA. Air quality standards for the concentration of particulate matter 2.5, global descriptive analysis. Bull World Health Organ 2021;99:125-37. https://doi.org/10.2471/BLT.19.245704

9. Samoli E, Peng R, Ramsay T, Pipikou M, Touloumi G, Dominici $F$, et al. Acute effects of ambient particulate matter on mortality in Europe and North America: results from the APHENA study. Environ Health Perspect. 2008 Nov; 116(11):1480-6. https://doi.org/10.1289/ehp. 11345

10. The United States Environment Protection Agency. Basic Information about NO2. https://www.epa.gov/no2pollution/basic-information-about-no2\#What $\% 20$ is $\% 20$ $\mathrm{NO}_{2}$

11. Hava Kalitesi Değerlendirme ve Yönetimi Yönetmeliği (Translated title: Air Quality Assessment and Management Regulation) https://www.mevzuat.gov.tr/mevzuat?Mev zuatNo=12188\&MevzuatTur=7\&MevzuatTertip $=5$

12. European Environment Agency. Air Quality e-Reporting products on EEA data service. 2018. https://ftp.eea. europa.eu/www/aqereporting-3/AQeReporting_ products_2018_v1.pdf (Accessed on 07.05.2021)

13. World Health Organization. WHO Air quality guidelines for particulate matter, ozone, nitrogen dioxide and sulfur dioxide. Global update 2005. https://apps.who.int/iris/ bitstream/handle/10665/69477/WHO_SDE_PHE_ OEH_06.02_eng.pdf ?sequence $=1$ (Accessed on 07.05.2021)

14. Republic of Turkey, Governorship of Istanbul. The City of Universities: Istanbul. 2019. http://en.istanbul.gov.tr/ the-city-of-universities-istanbul (Accessed on 20.02.2021).

15. IMM Open Data Portal. https://data.ibb.gov.tr/ (Accessed on 07.04.2021).

16. Greater London Authority. Air Pollution monitoring data in London: 2016 to 2020. February 2020. https://www. london.gov.uk/sites/default/files/air_pollution_ monitoring_data_in_london_2016_to_2020_feb2020. pdf

17. Tokyo Metropolitan Government/ Bureau of Environment. Air quality Monitoring. https://www.kankyo.metro. tokyo.lg.jp/en/automobile/monitoring.html

18. New York State Department of Environmental Conservation. Air Quailty Montoring. https://www.dec. ny.gov/chemcal/8406.html

19. European Environment Agency. Air Quality in Europe Report 2020. https://www.eea.europa.eu/publications/ air-quality-in-europe-2020-report

20. Union of Chambers of Turkish Engineers and Architechts (UCTEA)/ Chamber of Environmental Engineers. Hava 
Kirliliği Raporu 2019. (Translated title: Air Pollution Report 2019). https://www.tmmob.org.tr/sites/default/ files/2019.pdf (Accessed on 20.04.2021).

21. Pala K, Aykac N, Yasin Y. Premature deaths attributable to long-term exposure to $\mathrm{PM}_{2.5}$ in Turkey. Environ Sci Pollut Res 2021. https://doi.org/10.1007/s11356-021-13923-5

22. Çapraz Ö, Deniz A, Doğan N. Effects of air pollution on respiratory hospital admissions in İstanbul, Turkey, 2013 to 2015. Chemosphere 2017; 181:544-50. https://doi.org/10.1016/j.chemosphere.2017.04.105

23. Mentese S, Bakar C, Mirici NA, Oymak S, Otkun MT. Associations between respiratory health and ambient air quality in Canakkale, Turkey: a long-term cohort study. Environ Sci Pollut Res Int 2018;25(13):12915-3. https://doi.org/10.1007/s11356-018-1307-9

24. Kucharski AJ, Klepac P, Conlan AJK, Kissler SM, Tang ML, Fry H, Gog JR, Edmunds WJ; CMMID COVID-19 working group. Effectiveness of isolation, testing, contact tracing, and physical distancing on reducing transmission of SARS-CoV-2 in different settings: a mathematical modelling study. Lancet Infect Dis. 2020 Oct;20(10):1151 60.

https://doi.org/10.1101/2020.04.23.20077024

25. Di Domenico L, Pullano G, Sabbatini CE, Boelle Py, Colizza V. Impact of lockdown on COVID-19 epidemic in Île-de-France and possible exit strategies. BMC Med 18, 240 (2020). https://doi.org/10.1186/s12916-020-01698-4

26. Dawoud D. Emerging from the other end: Key measures for a successful COVID-19 lockdown exit strategy and the potential contribution of pharmacists. Res Social Adm Pharm 2021;17(1):1950-3. https://doi.org/10.1016/j.sapharm.2020.05.011

27. Liu Y, Morgenstern C, Kelly J, Lowe R. The impact of nonpharmaceutical interventions on SARS-CoV-2 transmission across 130 countries and territories. BMC Med 19, 40 (2021). https://doi.org/10.1186/s12916-020-01872-8

28. State of Global Air 2020. A global report card on air pollution exposures and their impacts on human health. https://www.stateofglobalair.org/resources (Accessed on 23.04.2021)

29. Dutheil F, Baker JS, Navel V. COVID-19 as a factor influencing air pollution? Environ Pollut 2020;263(Pt A): 114466 . https://doi.org/10.1016/j.envpol.2020.114466

30. Hörmann S, Jammoul F, Kuenzer T, Stadlober E. Separating the impact of gradual lockdown measures on air pollutants from seasonal variability. Atmos Pollut Res 2021;12(2):8492.

https://doi.org/10.1016/j.apr.2020.10.011

31. Hashim BM, Al-Naseri SK, Al-Maliki A, Al-Ansari N. Impact of COVID-19 lockdown on $\mathrm{NO}_{2}, \mathrm{O}_{3}, \mathrm{PM}_{2.5}$ and $\mathrm{PM}_{10}$ concentrations and assessing air quality changes in
Baghdad, Iraq. Sci Total Environ 2021;754:141978. https://doi.org/10.1016/j.scitotenv.2020.141978

32. Mahato S, Pal S, Ghosh KG. Effect of lockdown amid COVID-19 pandemic on air quality of the megacity Delhi, India. Sci Total Environ 2020;730:139086. https://doi.org/10.1016/j.scitotenv.2020.139086

33. Sahu KK, Kumar R. Preventive and treatment strategies of COVID-19: From community to clinical trials. J Family Med Prim Care 2020;9(5):2149-2157. https://doi.org/10.4103/jfmpc.jfmpc_728_20

34. Liu F, Wang M, Zheng M. Effects of COVID-19 lockdown on global air quality and health. Sci Total Environ 2021;755(Pt 1): 142533. https://doi.org/10.1016/j.scitotenv.2020.142533

35. Shehzad K, Xiaoxing L, Ahmad M, Majeed A, Tariq F, Wahab $S$. Does air pollution upsurge in megacities after Covid-19 lockdown? A spatial approach. Environ Res 2021;197:111052. https://doi.org/10.1016/j.envres.2021.111052

36. Baldasano JM. COVID-19 lockdown effects on air quality by $\mathrm{NO}_{2}$ in the cities of Barcelona and Madrid (Spain). Sci Total Environ 2020;741:140353. https://doi.org/10.1016/j.scitotenv.2020.140353

37. Vultaggio $M$, Varrica $D$, Alaimo $M G$. Impact on Air Quality of the COVID-19 Lockdown in the Urban Area of Palermo (Italy). Int J Environ Res Public Health 2020;17(20):7375. https://doi.org/10.3390/ijerph 17207375

38. Kanniah KD, Kamarul Zaman NAF, Kaskaoutis DG, Latif MT. COVID-19's impact on the atmospheric environment in the Southeast Asia region [published correction appears in Sci Total Environ. 2020;745:142200]. Sci Total Environ 2020;736:139658.

https://doi.org/10.1016/j.scitotenv.2020.139658

39. Berman JD, Ebisu K. Changes in U.S. air pollution during the COVID-19 pandemic. Sci Total Environ 2020;739:139864. https://doi.org/10.1016/j.scitotenv.2020.139864

40. Bhat SA, Bashir O, Bilal M, Ishaq A, Din Dar MU, Kumar $\mathrm{R}$, et al. Impact of COVID-related lockdowns on environmental and climate change scenarios. Environ Res. 2021 Apr; 195:110839. https://doi.org/10.1016/j.envres.2021.110839

41. Bao R, A. Zhang A. Does lockdown reduce air pollution? Evidence from 44 cities in northern China. Sci. Total Environ 731 (2020), p. 139052. https://doi.org/10.1016/j.scitotenv.2020.139052

42. Wang $M$, Liu F, Zheng $M$. Air quality improvement from COVID-19 lockdown: evidence from China [published online ahead of print, 2020 Nov 9]. Air Qual Atmos Health 2020;1-14. https://doi.org/10.1007/s1 1869-020-00963-y

43. Singh RP, Chauhan A. Impact of lockdown on air quality in India during COVID-19 pandemic [published online ahead of print, 2020 Jul 7]. Air Qual Atmos Health 
2020;1-8.

https://doi.org/10.1007/s11869-020-00863-1

44. Nakada LYK, Urban RC. COVID-19 pandemic: Impacts on the air quality during the partial lockdown in São Paulo state, Brazil. Sci Total Environ 2020;730:139087. https://doi.org/10.1016/j.scitotenv.2020.139087

45. Mendez-Espinosa JF, Rojas NY, Vargas J, Pachón JE, Belalcazar LC, Ramírez O. Air quality variations in Northern South America during the COVID-19 lockdown. Sci Total Environ 2020;749:141621.

https://doi.org/10.1016/j.scitotenv.2020.141621
46. Orak NH, Ozdemir O. The impacts of COVID-19 lockdown on $\mathrm{PM}_{10}$ and $\mathrm{SO}_{2}$ concentrations and association with human mobility across Turkey. Environ Res 2021;197:111018.

https://doi.org/10.1016/j.envres.2021.111018

47. Çelik E, Gül M. How Covid-19 pandemic and partial lockdown decisions a ect air quality of a city? The case of Istanbul, Turkey. Environ Dev Sustain 2021. https://doi. org/10.1007/s10668-021-01328-w https://doi.org/10.1007/s10668-021-01328-w 